\title{
AN UPDATE OF GENDER DIVERSITY IN EDITORIAL BOARDS: A LONGITUDINAL STUDY OF MANAGEMENT JOURNALS
}

\author{
Isabel Metz
}

Anne-Wil Harzing

Version November 2009

To be published in Personnel Review.

Copyright @ 2009-2010 Isabel Metz \& Anne-Wil Harzing All rights reserved.

Prof. Anne-Wil Harzing University of Melbourne

Department of Management \& Marketing Faculty of Economics \& Commerce

Parkville Campus

Melbourne, VIC 3010

Australia
Email: anne-wil@harzing.com

Web: www.harzing.com 
AN UPDATE OF GENDER DIVERSITY IN EDITORIAL BOARDS:

A LONGITUDINAL STUDY OF MANAGEMENT JOURNALS

ISABEL METZ

Melbourne Business School, University of Melbourne, 200 Leicester Street, Carlton

Victoria 3053, Australia

Tel: (61) (3) 83448226

Fax: (61) (3) 93498144

i.metz@mbs.edu
ANNE-WIL HARZING

Department of Management, University of Melbourne, Parkville Campus, Parkville Victoria 3010, Australia

Tel: (61) (3) 83443724

Fax: (61) (3) 93494293

harzing@unimelb.edu.au

\begin{abstract}
Purpose

This study updates our knowledge of women's representation on the boards of scholarly management journals with a longitudinal analysis of the same over two decades.

\section{Design/methodology/approach}

This study extends the work of Metz and Harzing (2009) on women’s representation in the editorial boards of 57 management journals from 1989 to 2004 by focusing on the development of gender diversity in editorial board membership over time. We first add another time period (2005-2009) to their data. We then add empirical richness by conducting a more fine grained analysis of women's representation at the various editorial board levels over time. In addition, this study analyses the development of female editorial board memberships over time for five management fields, journals of four different ranks, and two geographic regions. As a result, this study examines women's representation in the editorial boards of 57 management journals over a period of 20 years (from 1989 to 2009). 


\section{Findings}

Results showed an overall increase in women's representation in the editorial boards of these 57 management journals (at board member, associate editor and editor in chief levels) in the last five years (2004-2009) to 22.4\%. Despite several positive trends identified in this follow-up study, women's representation as editorial board members continues to be inconsistent across five management fields, across four journal rankings and across two geographic regions.

\section{Practical Implications}

This study's findings clearly indicate that there is still much that can be done to narrow the gender imbalance in most editorial boards of management journals. Monitoring women’s representation in editorial boards of management journals is only one of the steps needed for successful change to occur.

\section{Social implications}

This study's findings matter for our society because editorial board membership is a sign of one's scholarly recognition and valued in academic promotion processes. It is important, therefore, that this promotion criterion be evaluated in the context of up-to-date knowledge of the representation of women in editorial boards of management journals, otherwise its impact on women’s promotion could exacerbate an already discriminatory system of academic scholarship

\section{Originality/Value}

It is important to regularly monitor women's (under)representation on the boards of scholarly management journals to raise awareness that might lead to or sustain positive change. This follow-up study serves that purpose in the field of management, a largely neglected field until recently.

Keywords: Women, Gender diversity, Editorial Boards, Management Journals

Paper Type: Research Paper 


\section{Introduction}

There is an increasing awareness that the absence of women in positions of influence in business, such as on company boards, is detrimental to social and economic outcomes (e.g., European Commission, 2010). As a result, business agencies around the world are forcing change. For example, the Australian Stock Exchange (ASX) Corporate Governance Council announced gender diversity guidelines to publicly listed companies requiring them to monitor and report progress in gender diversity at all levels of the organisation (ASX, 2009). Similarly in academia, the absence of women in editorial boards of management journals (Metz and Harzing, 2009) is understood to be detrimental to the careers of female faculty (Özbilgin, 2009; Raelin, 2008), to the education of our business students (Jacobs, 2008; Offermann, 2007), and to the evolution of the management field (e.g., Özbilgin, 2009; Svensson and Wood, 2007). It is, therefore, important to regularly monitor women's representation on the boards of scholarly management journals to raise awareness of women's slimmer chances than men's of becoming editorial board members. Yet, there is no change mechanism through which we regularly monitor and report progress in the gender diversity of editorial boards of management journals. As a result, this study’s main objective is to update our knowledge of the representation of women in editorial boards of management journals by studying editorial board gender diversity over time. To our knowledge, Metz and Harzing’s (2009) study is the most recent and comprehensive study on this topic in the field of management; it analysed women's representation in the editorial boards of 57 management journals over a period of 15 years, from 1989 to 2004. The current study’s objectives are achieved by extending the work of Metz and Harzing (2009) from 15 to 20 years. Further, we provide a more fine grained understanding of female editorial board membership by examining their representation at various levels of the hierarchy within editorial boards. Finally, 
we analyse the development of female editorial board memberships over time for five management fields, journals of four different ranks, and two geographic regions.

\section{Literature review}

The study of editorial boards partly emanated from the challenges non-US scholars experienced in publishing in, and becoming editorial board members of, academic US journals in one’s field (e.g. Baruch, 2001; Hodgson and Rothman, 1999). More recently, as the number of female academics increased, so did the study of gender diversity in editorial boards of academic journals (Bourns and Addis, 2004). Nevertheless, most of what we know about women's representation in editorial boards of academic journals is descriptive in nature and unrelated to the field of management (e.g., Addis and Villa, 2003; Carnegie, McWatters and Potter, 2003; McSweeney, Donahoe and Swindell, 2000; White, 1985). To our knowledge, there are two studies of gender diversity in editorial boards in the management area: McGee, Bucklin, Dickinson and McSweeney (2003) and Metz and Harzing (2009). McGee et al.’s study, however, is descriptive and based on a small sample of four journals.

So, what we know thus far is that the progress in women's representation in editorial boards of management journals has been somewhat patchy. Metz and Harzing (2009) found an overall increase in the representation of women in editorial boards of management journals from 1989 to 2004, in line with women’s increase as senior (or first) authors in the same journals. However, across management journals, the change in women's representation over the period studied varied from $-9 \%$ (i.e., a decrease) to $28 \%$ and, as at 2004 , their proportion in editorial boards ranged from $0 \%$ and 44\%. Further, the gap between women's contribution as first authors and their representation as editorial board members remained intact from 1989 to 2004. These findings are disappointing, as they suggest that the barriers to female faculty becoming editorial 
board members are resilient and resistant to current beliefs and knowledge of the pivotal role of diversity in education and in organisations (Bell et al., 2009).

Although Metz and Harzing’s (2009) findings for women’s representation in editorial boards are disappointing, they mirror women’s slow progress in leadership positions in organizations in the last two decades (e.g., ([Australia’s] Equal Opportunity for Women in the Workplace Agency [EOWA] 2010; Powell, 2010). A business case for diversity exists (e.g., Robinson and Dechant, 1997). Yet, the literature on gender and diversity change in organizations shows that initial gains in women's representation in management are thwarted by factors resilient to change, such as organization cultures unwelcoming of women, male managers with vested interests in preserving those cultures, gender stereotypes, and lack of leader commitment to gender diversity change initiatives (e.g., Itzin and Newman, 1995; Powell 2010). In contrast, successful change efforts and sustainable increases in women's representation in leadership in organizations involve, for example, unequivocal senior leadership commitment, gender diversity targets, implementation of strategies to achieve targets and regular monitoring of performance against targets (e.g., McCracken, 2000; Metz and Kulik, 2008).

Therefore, it is important to regularly report on the status of women's representation on the editorial boards of academic management journals for two reasons. First, to increase awareness that might lead to positive change. Awareness of women's under-representation as editorial board members might prompt some journal editors and editorial board members to be more vigilant than they have been. This rationale is in line with the diversity literature, which shows that identifying a work barrier for women and giving it a name raises awareness, thus helping individuals and organisations to address it (Meyerson and Fletcher, 2000).

Second, gender diversity updates are necessary to sustain change efforts. As we now know, awareness is a necessary but often insufficient step for the sustained increase in the 
representation of women in leadership positions. We also know from the organisational change literature that the positive effects of initial change efforts can dissipate as time passes unless reinforced (Kotter, 1995). This dissipation of positive outcomes of change efforts has been shown to also occur with regard to efforts to change the international mix of editorial boards (Metz and Harzing, 2010). Therefore, it is important that change agents, such as journal editors and editorial board members, get regular updates on the progress in the gender diversity of management journals to avoid complacency.

Overall, we expect that women's representation in editorial boards of management journals in general, and at the various board levels in particular (e.g., editorial board member, associate editor, and chief editor), to follow a slow upward trend. This trend would be in line with women’s increasing representation in various academic fields and at higher levels of academia (Toutkoushian, 1999; White, 2003). Nevertheless, this expected increase in female editorial board membership will vary across fields in management, across journals within each field and across countries. We know, for example, that the proportion of female academics varies by area of study (Roos and Gatta, 2009) and the proportion of female professors varies by country (Özbilgin and Healy, 2004). As female academics largely populate the pipeline to female editorial board members of academic journals, their variable representation across areas of study (and country) is likely to be reproduced at the editorial board level of journals in each area (and country). Further, we now know that women's representation in editorial boards of management journals is predicted by editor’s gender and journal’s prestige (Metz and Harzing, 2009). Hence, any increase in women's representation in editorial boards of management journals is expected to be inconsistent across management fields and across countries.

\section{Method}


This study's main objective is to update our knowledge of women's representation on the boards of scholarly management journals by studying board gender diversity over time. To achieve this study’s aim we extended the work of Metz and Harzing (2009) by adding another five year period to their data and by conducting a more fine grained analysis of women's representation at the various editorial board levels. We also supplemented the earlier study by providing an analysis of the development of female editorial board memberships over time for five management fields, journals of four different ranks, and two geographic regions. As a result, this study examines women's representation in the editorial boards of 57 management journals over a period of 20 years (from 1989 to 2009). Five years is sufficient time for some change to have occurred since the last examination of the representation of women in editorial boards, and a 20 year period allows clear trends to be identified.

\subsection{Sample and Data Collection Procedures}

This study was based on archival data. We built on the information on female editorial board membership already collected by Metz and Harzing (2009) for a total of 57 academic journals. Hence, the unit of analysis for the current study continued to be the individual journal and journals in the same five areas were included: Operations Management, International Business, General Management and Strategy, Human Resource Management/Organizational Behavior/Industrial Relations (HRM/OB/IR), and Marketing. Although one could argue that Strategy and General Management are separate fields, we decided to follow the categorization in Harzing's Journal Quality List that combines the two. Given the relative paucity of journals focusing specifically on Strategy, it would have been difficult to incorporate this as a separate category. We also maintained the spread of North American and European journals as well as a range of journals of different standing, by selecting the same journals for each area of 
management. As a result, our sample still comprises eight Operations Management, nine International Business journals, and thirteen or fourteen journals for the other areas.

As we wanted to test if female editorial board representation increased over time, we added to the data already collected for 1989, 1994, 1999, and 2004 by collecting data for 2009. As done before (Metz and Harzing, 2009) for each journal, editorial board pages were accessed for the first 2009 issue and a multilingual research assistant coded the editorial board/editor data for gender. The gender was determined based on the editorial board member's/associate editor's/editor's given name wherever possible. If first/given names were gender neutral, we were normally able to ascertain gender through an Internet search. For the few non-Western names we also sought assistance from $\mathrm{PhD}$ students representing the countries in question. If we were still unable to resolve the gender, the name was coded as missing. This procedure was necessary for fewer than $5 \%$ of the editorial board members for most of the journals and between 5 and $10 \%$ of the editorial board members for five journals in Operations Management that had a high proportion of Chinese authors and/or listed only initials rather than full names. Hence, missing data are unlikely to have distorted our analyses.

We have some incomplete data for 1989 and 1994 for this study as for Metz and Harzing's (2009), because 5 (13) journals were either established after 1994 (1989) or did not have an editorial board in 1994 (1989). However, we have complete records for 57 journals in 2009, 2004 and 1999. Large differences exist in the size of the editorial boards across areas, with Marketing and Operations Management journals having significantly larger boards (between 1989 and 2009 on average 77 and 72 members, respectively) than journals in the area of International Business (45), HRM/OB/IR (47) and General Management and Strategy (57). However, as we used the proportion of female editorial board members for each journal, these 
differences do not distort our results. In total, more than 16,000 editorial board members were coded.

\subsection{Measures}

The proportion of female editorial board members was calculated by dividing the number of female editorial board members by the total number of board members in each of the four years. The proportion of female (associate) editors was calculated likewise by dividing the number of female (associate) editors by the total number of (associate) editors for each journal. Several journals have more than one editor in chief and two thirds of the journals have more than one associate editor, with eleven journals having more than 10 associate editors. Hence we calculated the proportion of female (associate) editors for each journal before averaging these variables for each time period.

Measuring the prestige of academic journals is fraught with problems. Thomson ISI impact factors are often used to assess journal prestige. However, many of the journals in our sample are not ISI listed. Moreover, the use of impact factors suffers from serious drawbacks (see e.g. Yeung, 2002). Hence, we used Harzing's collated Journal Quality List as the basis for our measure of journal prestige. As even this list has many missing values and it is difficult to summarize a multitude of rankings, we used the summary scores as provided by Mingers and Harzing (2007). They performed an extensive statistical analysis to classify journals into four groups, using both a wide range of rankings in the Harzing Journal Quality List and Thomson ISI impact factors for 2004. In their classification 1 stands for the lowest ranked journals and 4 stands for the highest ranked journals. We note that although we would have preferred to measure journal prestige separately for each of the five time periods, this was not feasible as rankings for previous years are not available. Moreover, journal rankings are generally relatively stable over time (see e.g. Podsakoff, MacKenzie, Bachrach and Podsakoff, 2005). 
The independent variable, the region in which the journal was established was measured as the country of affiliation of the editor. We focus on the editor, rather than on the country where the journal is published, as the editor generally has more influence on the choice of editorial board members than the publisher. Nevertheless, in the majority of cases the two countries are identical. As we intend to compare US journals with non-US journals, the non-US countries were subsequently aggregated to a category named European/Australian journals.

\section{Results}

Table 1 ranks the 57 journals in our sample in descending order by proportion of female editorial board membership. As can be easily verified, the variation is substantial, with the proportion of female editorial board members in 2009 ranging from 0\% for the European Journal of Operational Research to parity (50\%) for Journal of Vocational Behavior.

$<$ Take in Table (No. 1)>

It is important to note that the average size of the editorial board has increased steadily over the years from 40 academics in 1989 to 64 in 2004, and jumped to 87 in 2009. Expanding editorial boards present opportunities for editors and female academics; editors can address the gender imbalance without prematurely asking current board members to step down and, thus, female scholars have a higher chance of being selected. There are now five journals with an editorial board of more than 200 academics: Journal of Business Research, Industrial Marketing Management, Journal of Management, Strategic Management Journal, and Organization Science. As of 2009, twenty-one journals had an editorial board that exceeds 100 academics.

In this section, we first present the proportion of female board members followed by the proportion of female academics at the two highest levels of the editorial board structure: chief editors and associate editors. We then present the proportion of female board members by management field, by journal ranking, and by country or geographic area. 
Before proceeding, it is worth mentioning that we also collected data for managing editors and book review editors, but the number of journals with missing values for these variables was too high to draw any reliable conclusions. Overall though, the proportion of female book review editors was higher than the proportion of female incumbents for any of the other positions, except managing editors. Not surprisingly, the overwhelming majority of managing editors were female, although more recently the number of male managing editors seems to be increasing.

\subsection{Female editorial board members, associate editors and editors in chief}

The trends in women's representation as (associate) editors and editorial board members of management journals are clearly upward. As can be seen from Table 2 and Figure 1, the proportion of female editorial board members has steadily risen in the last 20 years. As at 2009, this representation is 22.4\%, significantly higher than in $2004(t=4.935, p=0.000)$. Further, the proportion of female editors in chief has also increased steadily after 1994, from a low of $8.5 \%$ in 1989 and $7.6 \%$ in 1994 to a high of $21.9 \%$ in 2009 . For the last three time periods, the proportion of female editors is very similar to the proportion of female editorial board members, with the latter being only 0.5 to $1 \%$ higher than the former. A paired t-test shows a significant increase of both female editors in chief $(\mathrm{t}=2.105, \mathrm{p}=0.041)$ and female editorial board members $(\mathrm{t}=12.70$, p=0.000) between 1989 and 2009.

$<$ Take in Table (No. 2) and Figure (No. 1)>

More specifically, there were 14 journals with one or more female editors in chief in 2009: Journal of Consumer Research, Journal of Marketing Management, Organization Science, Journal of Organizational Behavior, International Journal of Cross-Cultural Management, Industrial and Labor Relations Review, Journal of Management, Academy of Management Review, Human Resource Management, Thunderbird International Business Review, Journal of International Business Studies, Journal of Advertising, Decision Sciences Journal, California 
Management Review. We conclude that there is a reasonable spread of female editors in chief across the five sub-disciplines, as Marketing, IB and HRM all have three journals with female editors, General Management \& Strategy has four, and Operations Management has one.

When we analysed the proportion of female editors in chief across the two geographic regions, we found that of the 25 journals that have had a female editor at any stage in their history, only 16\% (or 4 journals) are European/Australasian-based, compared with 33\% European/Australasian-based journals in our total sample. Further, $72 \%$ of the journals (or 18 journals) with female editors in chief are ranked 3 or 4 , whereas $61 \%$ of the journals in our total sample are ranked 3 or 4 . It appears that women have a lower chance to be editors in chief in European/ Australasian-based journals than in US-based ones, and a higher chance in journals in the higher two ranks. As also shown in Metz and Harzing (2009) for female editorial board members, high-ranked journals seem to have a stronger tendency to promote female editorship than low-ranked journals.

In contrast to the steady increase in the proportion of women in editorial boards and in editor in chief positions, it is evident from Table 2 and Figure 1 that the proportion of female associate editors has remained fairly stable after the first significant increase in 1994 . However, it should be noted that the figures for both editors and associate editors are "lumpier" as they have fewer observations per journal. Overall though the trend for associate editors, shows a very significant increase $(t=-3.757, p=0.001)$ between 1989 and 2009. Further, the representation of women at the associate editor level has been consistently higher than their representation at board member or editor level, for the 20 years up to 2009. The difference with editors in chief is to be expected, as it would be natural to progress from associate editor to editor in chief. The difference between the proportion of female associate editors and female editorial board member might be caused by the lumpy nature of associate editor appointments; that is the appointment of 
one new female associate editor makes a far bigger difference to women's representation at associate editor level than the addition of one new female editorial board member makes to the gender diversity of the editorial board.

\subsection{Female editorial board members by management discipline, journal rank and geographic region}

As can be seen from Table 3 and Figure 2, there is a clear and steady upward trend in the representation of women in editorial boards of journals in each of the five management areas, with the possible exception of Operations.

$<$ Take in Table (No. 3) and Figure (No. 2)>

More specifically, just over a quarter of the journals in our sample now have more than $30 \%$ women on the editorial board. This includes three journals that are often considered to be at the top of the Management field overall (Administrative Science Quarterly [37\%], Academy of Management Review [35\%] and Academy of Management Journal [32\%]) as well as two of the top journals in Marketing (Journal of Advertising [37\%] and Journal of Consumer Research [34\%]). The Journal of Marketing lags behind with 16\%.

Only just over a quarter of the journals in our sample showed a decline in women's representation in their editorial board since 2004. This decline was generally very small, with only three journals experiencing a decline of 5\% or more. Furthermore, journals that experienced more than $1 \%$ decline were generally journals that still had higher than average representation of women on their editorial boards as of 2009. The only exceptions are three Operations journals for which women’s representation in editorial boards dropped below 10\% in 2009.

Despite the general upward trend in the representation of women in the editorial boards of most management journals in this study’s sample, the relative gender diversity (from least to most gender diverse) across the editorial boards of five management disciplines has remained 
intact in 20 years; Operations has consistently been the field of study with the least gender diverse editorial boards, followed by (in ascending order of gender diversity) International Business, Marketing, General Management \& Strategy and HRM/OB. Further, an ANOVA test on the proportion of female editorial board membership across the five areas revealed that differences in the gender diversity of editorial boards between sub-disciplines have widened over the years (1989: $F=2.792, p=0.039 ; 1994: F=2.404, p=0.063 ; 1999: F=4.214, p=0.005 ; 2004$ : $F=4.834, p=0.002 ; 2009: F=5.593, p=0.001)$.

It is clear from Table 4 and Figure 3 that the proportion of women in editorial boards of management journals of all ranking levels has improved over the 20 year period studied. However, for each of the five points in time, journals ranked 1 had the lowest proportion of female editorial board membership and journals ranked 4 had the highest; journals ranked 2 and 3 have had the second and the third highest proportion of female editorial board membership, respectively. As Table 4 shows, the absolute difference in female editorial board representation between the four levels has remained fairly stable over time. However, lower-ranked journals started from a lower base and hence their relative increase is larger than for the higher-ranked journals. The lower-ranked journals also showed a considerable increase in female editorial board members in the final 5-year period. As a result, differences in female editorial board membership between journals of different ranks are no longer significant in $2009(\mathrm{t}=1.670, \mathrm{p}=0.184)$.

$<$ Take in Table (No. 4) and Figure (No. 3)>

As Table 5 and Figure 4 show, there is clearly an upward trend in the proportion of women in editorial boards of management journals in both regions studied. However, US-based journals have always had the most gender diverse editorial boards since 1989. As a result, the absolute gap in the gender diversity of editorial boards between European/Australasian and US journals has stayed the same at approximately 7-9\%. However, European/Australasian journals 
started from a lower base and hence their relative increase is larger than for US journals. As can be seen from Table 5, in 1989, the proportion of female editorial board membership in European/Australasian journal was only a quarter of that of its US counterparts; in 2009 it had risen to nearly three quarters. Even so, the difference between European/Australasian and US journals is significant in each of the five time periods, ranging from $t=3.293, p=0.002$ in 1989 to $\mathrm{t}=2.510, \mathrm{p}=0.015$ in 2009 .

$<$ Take in Table (No. 5) and Figure (No. 4)>

\section{Discussion}

It is important to regularly monitor women’s (under)representation on the boards of scholarly management journals to raise awareness that might lead to or sustain positive change. Therefore, this study extends Metz and Harzing's (2009) study by examining the representation of women at the various editorial board levels of management journals for a period of 20 years, from 1989 to 2009, and by comparing the development of female editorial board membership over time for five areas of management, journals of four different ranks and two geographical areas. As predicted, we found a small, overall increase in women's representation in editorial boards of management journals (at board member, associate editor and editor in chief levels) in the last five years (2004-2009). Despite several positive trends identified in this study, women’s representation as editorial board members continues to be inconsistent across five management fields, across four journal rankings and across two geographic regions.

The representation of women in editorial boards increased between 2004 and 2009 by almost four percentage points to $22.4 \%$. This small but statistically significant increase augurs well for gender diversity in editorial boards of management journals because it shows an almost unbroken upward trend in women's representation since 1989. This trend reflects the efforts that some journals are making to increase the gender diversity of their boards and the fact that other 
journals are maintaining their lead in this area (e.g., Journal of Vocational Behavior, Group and Organization Management, Journal of Organizational Behavior).

This increase in the representation of women in editorial boards occurred for journals at all four levels of prestige and two regions. That said, the journals at the lowest level of the journal ranking system experienced the greatest gains between 2004 and 2009, and previous differences in female editorial board membership between journal ranks are no longer significant in 2009. Similarly, although US journals have always had the most gender diverse editorial boards, the proportion of women in the editorial boards of European/Australasian journals has improved most in the five years to 2009. It is not surprising, but nevertheless encouraging, that the most gains in the representation of women in editorial boards have been made by those journals that were trailing behind. This pattern of results indicates that journal prestige or country of publication is not, per se, a barrier to increasing women's representation in editorial boards. This pattern is encouraging because it shows that the efforts of journals and their editors to increase gender diversity is under their control rather than being inevitably tied to measures of journal quality or to cultural norms.

However, not all trends have been positive. As at 2009, women’s representation by management field ranged from just over $12 \%$ in Operations to almost 31\% in HRM/OB. Further, over the 20 year period studied, the differences in women's representation have increased between management fields rather than decreased. In particular, the representation of women in editorial boards of Operations journals appears to have stagnated in the last five years (from 2004 to 2009). This result might reflect a decline in female academics in the Operations discipline. However, population statistics indicate that this is unlikely to be the case. For example, in Australia, female employment rate continues to rise (Euromonitor International, 2010). Further, using female student graduation and enrolment figures as proxies of women's participation in 
various fields in academe, there is no indication of a decline in the proportion of women graduating (or enrolling) in Business and Management; in fact, their enrolment and graduation proportions have steadily increased and are now equivalent to men's (DEERW, 2010).

\section{Conclusion}

This study shows that the wide variability in the representation of women in editorial boards of management journals persists. In 2009, women's representation continues to vary from $0 \%$ (European Journal of Operations Management) to 50\% (Journal of Vocational Behavior). This study's findings clearly indicate that there is still much that can be done to narrow the gender imbalance in most editorial boards of management journals. Monitoring women’s representation in editorial boards of management journals is only one of the steps needed for successful change to occur (Kotter, 1995). Other necessary steps comprise providing a vision and developing a plan for change (e.g., as recently done by Özbilgin (2010), the new editor of the British Journal of Management). Further, gender diversity targets are beneficial in diversity change efforts, as are their regular monitoring (e.g., Itzin and Newman, 1995; McCracken, 2000; Metz and Kulik, 2008). As the process of selection of journal reviewers is often informal and relies on social networks (Brouns \& Addis, 2004), we suggest journal editors ask their social contacts to specifically nominate women in order to widen their search and achieve gender diversity targets.

The natural question is: what level of gender diversity should editors aim for? Kanter (1977) expounded the need for women to reach a "critical mass" in organisations for this change to be sustainable and its benefits realised. Recent empirical research suggests that the relationship between workforce gender diversity and organizational performance is curvilinear (rather than positively linear) and contingent on industry type (Ali, Kulik and Metz, in press; Richard, Murthi and Ismail, 2007). That is, neither is gender parity necessarily a desirable outcome nor is gender diversity similarly beneficial in different contexts. However, editorial board members do not 
work closely together, as do members of work groups in organizations. Therefore, the benefits of having a highly gender diverse editorial board is not hampered by negative group dynamics (e.g., conflict; Jehn, Northcraft and Neale, 1999), as are work groups in organizations. Hence, we suggest that gender parity, or at least a representation of women in editorial boards that reflects their representation in the field, would be desirable for editorial boards of academic journals.

Further, this study’s findings matter for our society (Özbilgin, 2010) by updating our knowledge of women's representation on the editorial boards of management journals. Editorial board membership is a sign of one’s scholarly recognition and valued in academic promotion processes (Raelin, 2008). It is important, therefore, that this promotion criterion be evaluated in the context of up-to-date knowledge of the representation of women in editorial boards of management journals, otherwise its impact on women's promotion could exacerbate an already discriminatory system of academic scholarship (e.g., Roos and Gatta, 2009).

\section{References}

Addis, E. and Villa, P. (2003), “The editorial boards of Italian economics journals: Women, gender and social networking”, Feminist Economics, Vol. 9 No. 1, pp. 75-91.

Ali, M., Kulik, C. T., and Metz, I. (in press). "The organisational gender diversity-performance link: Does industry type matter?”, International Journal of Human Resource Management.

Australian Securities Commission (ASX) (2009), New ASX Corporate Governance Council Recommendations on Diversity, Media release, ASX, 7 December, Sydney.

Baruch, Y. (2001), “Global of North American? A geographical based comparative analysis of publications in top management journals”, International Journal of Cross Cultural Management, Vol. 1, Issue 1, pp. 109-126.

Baruch, Y., Konrad, A.M., Aguinis, H. and Starbuck, W.H. (2008), Opening the black box of 
editorship. Palgrave Macmillan, Houndmills, Basingstoke, Hampshire.

Bedeian, A.G. (2008), "Balancing authorial voice and editorial omniscience”, in Baruch, Y., Konrad, A.M., Aguinis, H. and Starbuck, W.H. (Eds.), Opening the black box of editorship, Palgrave Macmillan, Houndmills, Basingstoke, Hampshire, pp 134-142.

Bell, M.P., Connerley, M.L. and Cocchiara, F.K. (2009), “The case for mandatory diversity education”, Academy of Management Learning \& Education, Vol. 8, pp. 597- 609.

Brouns, M., and E. Addis. (2004), “Part I - Synthesis report on the workshop”, in European Commission, Gender and Excellence in the Making, European Communities, Office for Official Publications of the European Communities, Luxembourg, pp. 9-32.

Carnegie, G. D., McWatters, C. S. and Potter, B. N. 2003. “The development of the specialist accounting history literature in the English language: An analysis by gender”, Accounting, Auditing \& Accountability Journal, Vol. 16, pp. 186-207.

DEEWR (Department of Education, Employment and Workplace Relations), http://www.deewr.gov.au/HigherEducation/Publications/HEStatistics/Publications/Pages/Stu dents.aspx, (Accessed 11 May 2010).

EOWA. 2010. Australian Census of Women Executive Managers and Board of Directors. Australia: EOWA.

Euromonitor International (2010), Employment forecasts, Accessed 24 March 2010.

European Commission (2010), More women in senior positions key to economic stability and growth. Publications Office of the EU, Luxembourg.

Hodgson, G.M. and Rothman, H. (1999), “The editors and authors in economics journals: A case of institutional oligopoly?”, The Economics Journal, Vol. 109, pp. F165-F186.

Itzin, C. and Newman, J. (1995), Gender, culture and organizational change: Putting theory into practice, Routledge, London. 
Jacobs, J.A. (2008), “The case for an activist editorial model”, in B.Y., Konrad, A.M., Aguinis, H. and Starbuck, W.H. (Eds.), Opening the black box of editorship, Palgrave Macmillan, Houndmills, Basingstoke, Hampshire, pp. 134-142.

Jehn, K.A., Northcraft, G.B. and Neale, M.A. (1999), "Why differences make a difference: a field study of diversity, conflict, and performance in workgroups”, Administrative Science Quarterly, Vol. 44, Issue 4, pp. 741-63.

Kanter, R.M. (1977). Men and women of the corporation. Basic Books, New York. Kotter, J.P. (1995), “Leading change”, Harvard Business Review, Vol. 73 No. 2, pp. 59-67. McCracken, D.M. (2000), “Winning the war for women: Sometimes it takes a revolution”, Harvard Business Review, November-December, pp. 159-167.

McGee, H.M., Bucklin, B.R., Dickinson, A.M. and McSweeney, F.K. (2003), "Participation of women in the Journal of Organizational Behavior Management”, Journal of Organizational Behavior Management, Vol. 23 (1), pp. 3-30.

McSweeney, F. K., Donahoe, P. and Swindell, S. (2000), “Women in applied behavior analysis”, The Behavior Analyst, Vol. 23, pp. 267-277.

Metz, I. and Harzing, A.W. (2009), “Gender diversity in editorial boards of management journals”, Academy of Management Learning \& Education, Vol. 8, pp. 540-557.

Metz, I. and Harzing, A.W. (2010), “Practicing what we preach”, paper presented at the International Conference on Economics, Business Management and Marketing, Paris. Metz, I. and Kulik, C.T. (2008), “Making public organizations more inclusive: A case study of the Victoria police force”, Human Resource Management, Vol. 47, pp. 369-387.

Meyerson, D.E. and Fletcher, J.K. (2000), “A modest manifesto for shattering the glass ceiling”, Harvard Business Review, January-February, pp. 127-136.

Offermann, L. R. (2007), “From the editor: Not your father’s business school”, Academy of 
Management Learning \& Education, Vol. 6, pp. 165-166.

Özbilgin, M. (2009), “From journal rankings to making sense of the world”, Academy of Management Learning \& Education, Vol. 8 No. 1, pp. 113-121.

Özbilgin, M. (2010), “Scholarship of consequence: New directions for the British Journal of Management”, British Journal of Management, Vol. 21 No. 1, pp. 1-6.

Özbilgin, M. and Healy, G. (2004), “The gendered nature of career development of university professors: The case of Turkey”, Journal of Vocational Behaviour, Vol. 64, pp. 358-371.

Podsakoff, P.M., Mackenzie, S.B., Bachrach, D.G. and Podsakoff, N.P. (2005), “The influence of Management journals in the 1980s and 1990s”, Strategic Management Journal, Vol. 26, pp. 473-488.

Powell, G. (2010), Women and men in management. Sage Publications, California.

Raelin, J.A. (2008), "Refereeing the game of peer review”, Academy of Management Learning \& Education, Vol. 7, pp. 124-129.

Richard, O.C., Murthi, B.P.S. and Ismail. K. (2007), "The impact of racial diversity on intermediate and long-term performance: The moderating role of environmental context”, Strategic Management Journal, Vol. 28, Issue 12, pp. 1213-1233.

Robinson, G. and Dechant, K. (1997), “Building a business case for diversity”, Academy of Management Executive, Vol. 11, Issue 3, pp. 21-31.

Roos, P.A. and Gatta, M.L. (2009), “Gender (in)equity in the academy”, Research in Social Stratification and Mobility, Vol. 7, pp. 177-200.

Svensson, G. and Wood, G. (2007), "Point of view: Ethnocentricity in academic marketing journals”, Marketing Intelligence \& Planning, Vol. 25, pp. 252-270.

Toutkoushian, R.K. (1999), “The status of academic women in the 1990s”, The Quarterly Review of Economics and Finance, Vol. 39, pp. 679-698. 
Tsui, A.S. and Hollenbeck, J.R. (2009), “Successful authors and effective reviewers”, Organizational Research Methods, Vol. 12, pp. 259-275.

Yeung, H.W.-c. (2002), “Commentaries”, Environment and Planning A, Vol. 34, pp. 2093-2106.

White, A. (1985), “Women as authors and editors of psychology journals. A 10-year perspective”, American Psychologist, Vol. 40, pp. 527-530.

White, K. (2003), “Women and leadership in higher education in Australia”, Tertiary Education and Management, Vol. 9, pp. 45-60. 
Table 1: Journals in our sample order by average proportion of female editorial board members 1989-2009, with 2009 as secondary ordering

\begin{tabular}{|c|c|c|c|c|c|c|c|c|}
\hline Journal Title & Average & 2009 & 2004 & 1999 & 1994 & 1989 & Founded & Research Area \\
\hline Journal of Vocational Behavior & $45 \%$ & $50 \%$ & $47 \%$ & $43 \%$ & $54 \%$ & $32 \%$ & 1971 & HRM \& Org. Behavior \\
\hline Group \& Organization Management & $33 \%$ & $43 \%$ & $46 \%$ & $36 \%$ & $24 \%$ & $18 \%$ & 1976 & HRM \& Org. Behavior \\
\hline Journal of Organizational Behavior & $33 \%$ & $42 \%$ & $36 \%$ & $42 \%$ & $30 \%$ & $17 \%$ & 1980 & HRM \& Org. Behavior \\
\hline International Journal of Cross-Cultural Management & $33 \%$ & $36 \%$ & $32 \%$ & $32 \%$ & - & - & 2001 & International Business \\
\hline Academy of Management Journal & $31 \%$ & $27 \%$ & $29 \%$ & $35 \%$ & $39 \%$ & $22 \%$ & 1958 & General Management \& Strategy \\
\hline European Journal of Industrial Relations & $30 \%$ & $34 \%$ & $29 \%$ & $25 \%$ & - & - & 1995 & HRM \& Org. Behavior \\
\hline Organization Science & $29 \%$ & $42 \%$ & $47 \%$ & $29 \%$ & $5 \%$ & $23 \%$ & 1990 & General Management \& Strategy \\
\hline Administrative Science Quarterly & $29 \%$ & $37 \%$ & $29 \%$ & $28 \%$ & $32 \%$ & $21 \%$ & 1956 & General Management \& Strategy \\
\hline Journal of Consumer Research & $29 \%$ & $34 \%$ & $36 \%$ & $28 \%$ & $28 \%$ & $19 \%$ & 1974 & Marketing \\
\hline Academy of Management Review & $28 \%$ & $35 \%$ & $37 \%$ & $30 \%$ & $20 \%$ & $18 \%$ & 1976 & General Management \& Strategy \\
\hline Journal of Applied Psychology & $28 \%$ & $28 \%$ & $33 \%$ & $34 \%$ & $21 \%$ & $22 \%$ & 1917 & HRM \& Org. Behavior \\
\hline Organizational Behavior and Human Decision Processes & $27 \%$ & $41 \%$ & $25 \%$ & $26 \%$ & $26 \%$ & $18 \%$ & 1951 & HRM \& Org. Behavior \\
\hline Journal of Advertising & $25 \%$ & $37 \%$ & $25 \%$ & $22 \%$ & $14 \%$ & NEB & 1972 & Marketing \\
\hline Journal of Management & $22 \%$ & $30 \%$ & $26 \%$ & $26 \%$ & $19 \%$ & $10 \%$ & 1975 & General Management \& Strategy \\
\hline Asia Pacific Journal of Human Resources & $22 \%$ & $29 \%$ & $24 \%$ & $20 \%$ & $21 \%$ & $14 \%$ & 1963 & HRM \& Org. Behavior \\
\hline Academy of Management Executive & $21 \%$ & $32 \%$ & $13 \%$ & $18 \%$ & $22 \%$ & $19 \%$ & 1987 & General Management \& Strategy \\
\hline Human Resource Management & $21 \%$ & $31 \%$ & $33 \%$ & $13 \%$ & $11 \%$ & $15 \%$ & 1962 & HRM \& Org. Behavior \\
\hline Journal of World Business & $21 \%$ & $24 \%$ & $13 \%$ & $14 \%$ & $32 \%$ & $22 \%$ & 1966 & International Business \\
\hline Industrial Relations & $20 \%$ & $21 \%$ & $22 \%$ & $17 \%$ & $29 \%$ & $13 \%$ & 1961 & HRM \& Org. Behavior \\
\hline Journal of International Management & $20 \%$ & $18 \%$ & $17 \%$ & $24 \%$ & - & - & 1995 & International Business \\
\hline Organization Studies & $18 \%$ & $29 \%$ & $24 \%$ & $24 \%$ & $10 \%$ & $5 \%$ & 1980 & HRM \& Org. Behavior \\
\hline International Journal of Human Resource Management & $18 \%$ & $22 \%$ & $18 \%$ & $17 \%$ & $14 \%$ & - & 1990 & HRM \& Org. Behavior \\
\hline Journal of Marketing & $17 \%$ & $16 \%$ & $17 \%$ & $22 \%$ & $25 \%$ & $5 \%$ & 1936 & Marketing \\
\hline California Management Review & $16 \%$ & $31 \%$ & $21 \%$ & $17 \%$ & $4 \%$ & $5 \%$ & 1958 & General Management \& Strategy \\
\hline Personnel Psychology & $16 \%$ & $27 \%$ & $18 \%$ & $13 \%$ & $11 \%$ & $10 \%$ & 1948 & HRM \& Org. Behavior \\
\hline Production and Operations Management & $16 \%$ & $24 \%$ & $20 \%$ & $11 \%$ & $9 \%$ & - & 1992 & Operations Management \\
\hline Journal of Occupational and Organizational Psychology & $15 \%$ & $21 \%$ & $20 \%$ & $21 \%$ & $12 \%$ & $0 \%$ & 1928 & HRM \& Org. Behavior \\
\hline Journal of Retailing & $15 \%$ & $19 \%$ & $16 \%$ & $15 \%$ & $14 \%$ & $12 \%$ & 1925 & Marketing \\
\hline
\end{tabular}




\begin{tabular}{|c|c|c|c|c|c|c|c|c|}
\hline MIT Sloan Management Review & $15 \%$ & $13 \%$ & $12 \%$ & $22 \%$ & $20 \%$ & $7 \%$ & 1959 & General Management \& Strategy \\
\hline Strategic Management Journal & $14 \%$ & $25 \%$ & $17 \%$ & $13 \%$ & $7 \%$ & $6 \%$ & 1980 & General Management \& Strategy \\
\hline Journal of Marketing Research & $14 \%$ & $23 \%$ & $18 \%$ & $19 \%$ & $12 \%$ & $0 \%$ & 1964 & Marketing \\
\hline Journal of International Business Studies & $14 \%$ & $21 \%$ & $24 \%$ & $10 \%$ & $4 \%$ & $13 \%$ & 1970 & International Business \\
\hline Decision Sciences Journal & $14 \%$ & $20 \%$ & $18 \%$ & $14 \%$ & $11 \%$ & $6 \%$ & 1970 & Operations Management \\
\hline Journal of Business Research & $14 \%$ & $19 \%$ & $14 \%$ & $14 \%$ & $14 \%$ & $11 \%$ & 1973 & Marketing \\
\hline Journal of the Academy of Marketing Science & $13 \%$ & $24 \%$ & $13 \%$ & $12 \%$ & $7 \%$ & $8 \%$ & 1972 & Marketing \\
\hline Journal of Marketing Management & $12 \%$ & $23 \%$ & $18 \%$ & $16 \%$ & $5 \%$ & $0 \%$ & 1985 & Marketing \\
\hline Australasian Marketing Journal & $12 \%$ & $14 \%$ & $15 \%$ & $6 \%$ & NEB & - & 1993 & Marketing \\
\hline European Journal of Marketing & $11 \%$ & $24 \%$ & $14 \%$ & $6 \%$ & $10 \%$ & $0 \%$ & 1971 & Marketing \\
\hline Thunderbird International Business Review & $10 \%$ & $21 \%$ & $7 \%$ & $11 \%$ & $12 \%$ & $0 \%$ & 1959 & International Business \\
\hline Technovation & $10 \%$ & $16 \%$ & $11 \%$ & $11 \%$ & $5 \%$ & $6 \%$ & 1981 & Operations Management \\
\hline International Journal of Research in Marketing & $10 \%$ & $12 \%$ & $9 \%$ & $14 \%$ & $13 \%$ & $3 \%$ & 1984 & Marketing \\
\hline Management Science & $10 \%$ & $12 \%$ & $12 \%$ & $10 \%$ & $8 \%$ & $6 \%$ & 1954 & Operations Management \\
\hline Industrial and Labor Relations Review & $9 \%$ & $16 \%$ & $17 \%$ & $11 \%$ & $0 \%$ & $0 \%$ & 1947 & HRM \& Org. Behavior \\
\hline British Journal of Management & $9 \%$ & $12 \%$ & $10 \%$ & $7 \%$ & $7 \%$ & - & 1990 & General Management \& Strategy \\
\hline International Journal of Business Performance Management & $9 \%$ & $8 \%$ & $11 \%$ & $10 \%$ & - & - & 1999 & Operations Management \\
\hline Journal of Operations Management & $9 \%$ & $8 \%$ & $16 \%$ & $12 \%$ & $8 \%$ & $2 \%$ & 1980 & Operations Management \\
\hline Industrial Marketing Management & $8 \%$ & $18 \%$ & $10 \%$ & $6 \%$ & $3 \%$ & $3 \%$ & 1971 & Marketing \\
\hline Asia Pacific Journal of Management & $8 \%$ & $13 \%$ & $3 \%$ & $6 \%$ & $8 \%$ & - & 1984 & General Management \& Strategy \\
\hline Marketing Science & $7 \%$ & $11 \%$ & $11 \%$ & $7 \%$ & $6 \%$ & $3 \%$ & 1982 & Marketing \\
\hline Operations Research & $7 \%$ & $11 \%$ & $8 \%$ & $10 \%$ & $3 \%$ & $1 \%$ & 1952 & Operations Management \\
\hline Multinational Business Review & $7 \%$ & $10 \%$ & $6 \%$ & $7 \%$ & $3 \%$ & NEB & 1993 & International Business \\
\hline International Studies of Management \& Organization & $7 \%$ & $7 \%$ & $7 \%$ & $6 \%$ & $10 \%$ & $5 \%$ & 1971 & International Business \\
\hline Long Range Planning & $5 \%$ & $9 \%$ & $5 \%$ & $0 \%$ & $6 \%$ & $5 \%$ & 1968 & General Management \& Strategy \\
\hline Management International Review & $4 \%$ & $15 \%$ & $2 \%$ & $2 \%$ & $0 \%$ & $0 \%$ & 1961 & International Business \\
\hline International Business Review & $3 \%$ & $9 \%$ & $0 \%$ & $2 \%$ & $2 \%$ & - & 1992 & International Business \\
\hline European Management Journal & $1 \%$ & $5 \%$ & $0 \%$ & $0 \%$ & $0 \%$ & $0 \%$ & 1983 & General Management \& Strategy \\
\hline European Journal of Operational Research & $1 \%$ & $0 \%$ & $3 \%$ & $0 \%$ & $2 \%$ & $0 \%$ & 1977 & Operations Management \\
\hline
\end{tabular}


Table 2

Proportion of female editorial board members, female editors in chief and female associate editors in the last 20 years

\begin{tabular}{cccc}
\hline Year & EB Members & Associate Editors & Editors in Chief \\
\hline 1989 & $9.4 \%$ & $10.9 \%$ & $8.5 \%$ \\
1994 & $13.7 \%$ & $20.6 \%$ & $7.6 \%$ \\
1999 & $16.6 \%$ & $21.7 \%$ & $15.5 \%$ \\
2004 & $18.7 \%$ & $19.7 \%$ & $18.1 \%$ \\
2009 & $22.4 \%$ & $24.0 \%$ & $21.9 \%$ \\
\hline
\end{tabular}

Table 3

Proportion of female editorial boards members of journals in five management disciplines

\begin{tabular}{|c|c|c|c|c|c|}
\hline Year & Operations & $\begin{array}{c}\text { International } \\
\text { Business }\end{array}$ & Marketing & $\begin{array}{c}\text { General } \\
\text { Management \& } \\
\text { Strategy }\end{array}$ & $\begin{array}{c}\text { Human Resource } \\
\text { Management/ } \\
\text { Org. Behaviour }\end{array}$ \\
\hline 1989 & $3.7 \%$ & $8.0 \%$ & $5.7 \%$ & $12.3 \%$ & $13.7 \%$ \\
\hline 1994 & $6.6 \%$ & $9.0 \%$ & $12.5 \%$ & $14.5 \%$ & $20.1 \%$ \\
\hline 1999 & $9.9 \%$ & $12.0 \%$ & $14.3 \%$ & $17.8 \%$ & $24.5 \%$ \\
\hline 2004 & $12.4 \%$ & $12.0 \%$ & $16.7 \%$ & $19.2 \%$ & $28.0 \%$ \\
\hline 2009 & $12.3 \%$ & $17.8 \%$ & $21.1 \%$ & $23.8 \%$ & $30.9 \%$ \\
\hline
\end{tabular}


Table 4

Proportion of female editorial board members of journals by rank / prestige

\begin{tabular}{ccccc}
\hline Year & Rank 1 & Rank 2 & Rank 3 & Rank 4 \\
\hline $\mathbf{1 9 8 9}$ & $2 \%$ & $6 \%$ & $10 \%$ & $13 \%$ \\
$\mathbf{1 9 9 4}$ & $5 \%$ & $9 \%$ & $16 \%$ & $17 \%$ \\
$\mathbf{1 9 9 9}$ & $11 \%$ & $11 \%$ & $19 \%$ & $21 \%$ \\
$\mathbf{2 0 0 4}$ & $12 \%$ & $13 \%$ & $21 \%$ & $24 \%$ \\
\hline
\end{tabular}

Table 5

Proportion of female editorial board members of journals by region and relative proportion of European/Australian female editorial board membership compared to US female editorial board membership

\section{Relative proportion}

\begin{tabular}{lccc} 
Year & Europe/Australasia & US & (E/A divided by US) \\
\hline $\mathbf{1 9 8 9}$ & $3 \%$ & $12 \%$ & $25 \%$ \\
$\mathbf{1 9 9 4}$ & $8 \%$ & $16 \%$ & $47 \%$ \\
$\mathbf{1 9 9 9}$ & $12 \%$ & $19 \%$ & $61 \%$ \\
$\mathbf{2 0 0 4}$ & $13 \%$ & $22 \%$ & $61 \%$ \\
$\mathbf{2 0 0 9}$ & $17 \%$ & $25 \%$ & $70 \%$ \\
\hline
\end{tabular}


Figure 1: Proportion of female editorial board members, female associate editors and female editors in chief in the last 20 years



Figure 2: Proportion of female editorial boards members of journals in five management disciplines

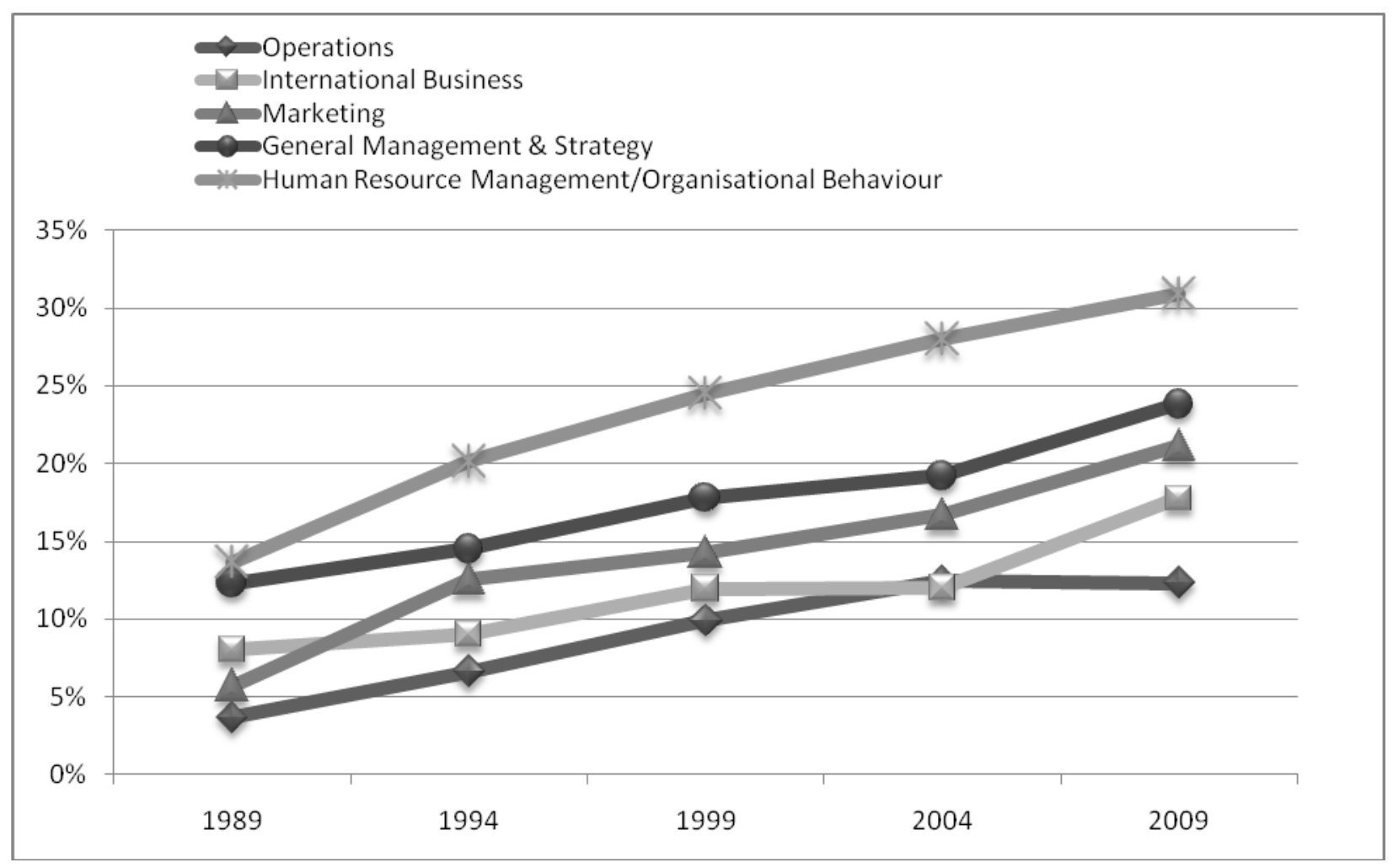


Figure 3: Proportion of female editorial board members of journals by rank / prestige

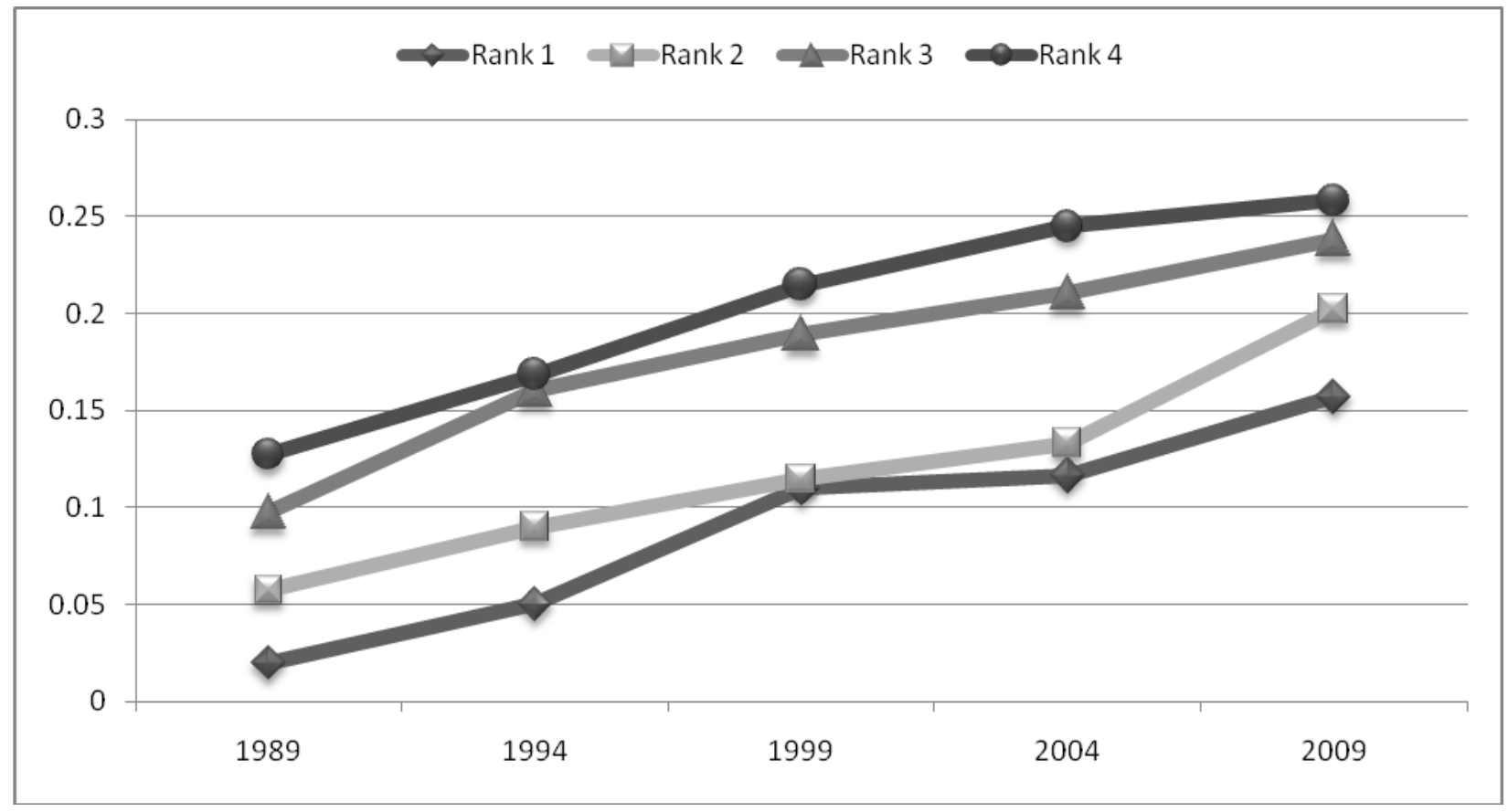

Figure 4: Proportion of female editorial board members of journals by region

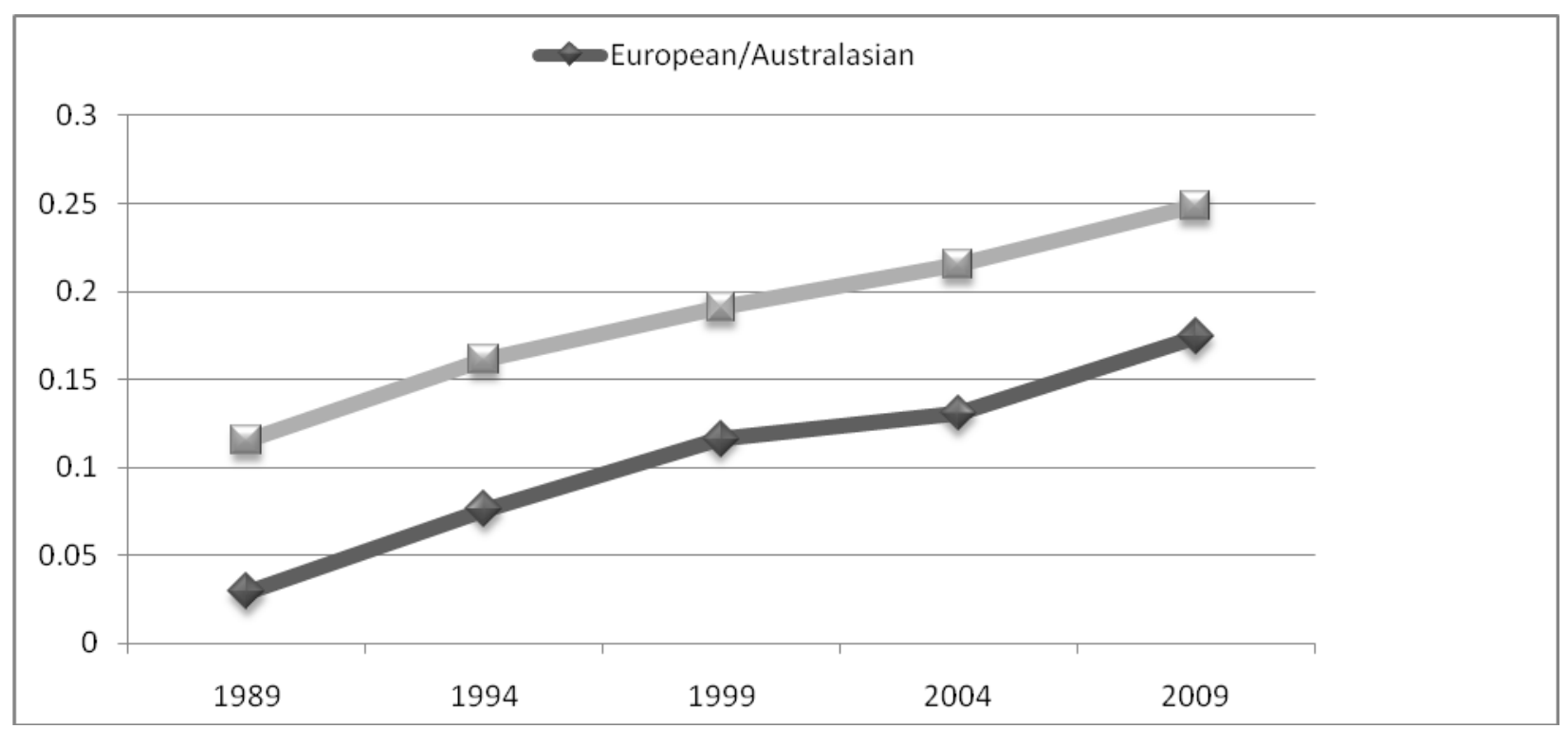

